\title{
郊外住宅団地における平常時と災害後の交流活動の変化 一仙台市鶴ヶ谷団地の戸建住宅を対象としてー \\ CHANGE OF COMMUNICATION ACTIVITIES IN SUBURBAN RESIDENTIAL AREA, BETWEEN NORMAL TIME AND AFTER DISASTER
}

- The case of detached housing area Turugaya residential district in Sendai city -

\author{
吉村 東*, 石坂公一** \\ Azuma YOSHIMURA and Koichi ISHIZAKA
}

\begin{abstract}
This study aims to make clear the factors and characteristics of people in communication activities responding to East Japan great earthquake disaster by focusing on the consciousness and actual condition of the communication activities in detached housing area, 1. Changes in communication activities of a normal time and after disaster

People who were active in normal times have a tendency for exchanging with neighboring more after disaster. On the contrary, people who were not very active, have a tendency for specializing in communication with families and relatives.

2. Characteristics from the viewpoint of consciousness

The type of "limited" limits their communication partner to "hobby and friend". The type of "not" can not have communication due to "Facility", "Aging" and "Disease".

3. Complaints and demands

The current complains are "neighborhood association" , "the way of neighborhood association in disaster" , "response of city government of evacuation" and "construction schedule of ditch digging". The demands are "restoration of citizen center", "proliferation of meeting place", "improving shopping center" and "evacuation drill in normal time".
\end{abstract}

Keywords : Change of Communication Activity, Suburban residential area, Social capital, Area management,

Normal time and after disaster, Communication consciousness

交流活動の変化, 郊外住宅団地, 社会関係資本, 地域マネジメント, 平常時と災害後, 交流意識

\section{1. はじめに}

近年、地方中核都市における造成から約 30 年以上過ぎた古い郊外 住宅地では少子高齢化が進行しており、経年に伴い継続居住世帯の 多くは夫婦のみ世帯や単独世帯となり、現在では高齢者の集積地区 となっている。仙台市においても郊外部の住宅団地では高齢化が進 行しており、独居高齢者が増加する中、家族や友人が減少するとと もに地域社会とのつながりも希薄化し、社会関係資本としてのコミ ユニティの紐帯の弱体化が危惧されている。一方で通信機器の発達 により直接人に会わない形での交流活動の質が大幅に向上する等、 住民間の交流活動を支える技術的環境が大きく変化し、新たな交流 活動の可能性も期待されている。また、平成 23 年に起きた東日本大 震災により住民間の交流活動の姿も大きく変化したと考えられる。

著者らはこれまで、郊外住宅団地における高齢者を中心とした居 住者の交流活動を社会関係資本のひとつとして捉え、今後の高齢化 に対応した地域マネジメントのあり方を検討するための基䃈として その実態についての分析 ${ }^{1 \cdot 2)}$ を行ってきた。これまでの調查注 ${ }^{11}$ によれば、交流活動の実態の中で問題を抱えている高齢者は、意識 の面で問題を感じている人が多く見られ、男女とも、生来の性格的 な問題・住民間の交流感情・家族の介護 - 身体状態 - 加齢等に加え て、機器操作の知識・迷惑メールや電話、セールスなどが問題とな
つている。また調査の自由記述回答欄の「語」の分析注 2) からも「男 性」の方で、本人の性格面からの交流の煩わしさ・健康上・機器操 作等の要因が抽出されている。また、今後、高齢化の進展にともな い通信機器注3) を使った交流活動が、直接会っての交流活動の補完 的役割を果たしていくことを考えると、これらの機器についてのリ テラシーの向上により、社会関係資本の充実化が図られる可能性も うかがえた。一方、災害を契機とした住宅地・住宅における居住者 の実態・意識や変化等に関する既往研究としては、「住宅地としての

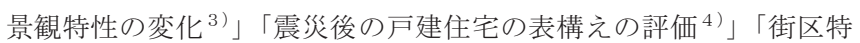
性から見た住宅再建 ${ }^{5)}$ 等戸建住宅地に関するものや「コミュティ の再構築 ${ }^{6)} 」 「$ 災害復興住宅におけるコミュニティの変化の実態 ${ }^{7)} 」$ 等コミュニティに関するもの、「災害時における大規模住宅供給 ${ }^{8)} 」$ 等住宅供給に関寸るものなどが挙げられるが、「高齢者の交流活動」 を社会関係資本注4) の一端として捉えて平常時注5) と災害後の変化 について分析したものは見られない。

本研究では、高齢化に対応した地域の社会関係資本のあり方を検 討する一環として、東日本大震災を対象に平常時と災害後の団地居 住者の「交流活動の実態」と「交流活動をめぐる住民の意識」の変 化に着目し、被災体験が地域の交流活動に与えた影響を明らかにす ることを目的とする。

\footnotetext{
* 東北大学大学院工学研究科都市 $\cdot$ 建築学専攻 大学院生.工修

** 東北大学災害科学国際研究所 教授・工博
}

Graduate Student, Dept. of Architecture, Univ. of Tohoku, M. Eng.

Prof., International Research Institute of Disaster Science, Univ. of Tohoku, Dr. Eng. 


\section{2. 研究の方法}

本研究は高齢化にともない、高齢者の交流活動が社会関係資本の 前提条件としての意味を強めつつあると考えられる郊外住宅地を対 象地域とし、居住者に対して交流活動に関するアンケート調查によ りデータを収集した。交流状況を把握する方法としてはアンケート 方式の他にも個別の聞き取りやグループヒアリング等の方法も考え られるが、まとまったサンプル数が得られ質問項目相互間の関連性 が分析できる点、自由記述回答欄を設けることで聞き取り調查に近 い生の情報が得られる点等を考慮して、本研究ではアンケート方式 を採用した。分析の対象者は当該地域に造成時から継続居住してい る 65 歳以上の高齢者であるが、調査実施にあたっては 65 歳未満の 人も調查対象とし、65 歳未満層との比較により高齢者の特性をより 明確に把握することが可能となるようにした。なお、アンケートの 記入にあたっては世帯の中で一番の高齢者の方にお願いした。

また、交流活動の特性については、居住者属性との関連で分析を 行うとともに、「交流活動をめぐる意識」については、調查の自由記 述回答欄注6) の記述を内容別に類型化して分析を行った。

なお、本研究では「交流活動」を(1直接顔を合わせて何らかのコ ミュニケーションをする行為（直接会話）と、現在、直接会話の補 完としての役割が増大しつつあると考えられる(2)電話やメールなど 通信機器を利用してコミュニケーションをする行為（機器通話）の 2 つの行為に大別している。

\section{3. 調査の対象と概要}

調查対象地は、地方中核都市仙台市の郊外に位置する住宅団地で、 造成時の計画人口が 10,000 人以上の団地注 7 )の中で、(1)造成時期が 昭和 $40 \sim 50$ 年と古く高齢者率が高い、(2)仙台駅からの距離が $5 \sim 10$ $\mathrm{km}$ 圈内で、(3)住居形態の特性の相違が見られる戸建住宅・集合住宅 のどちらも有し、(4)団地内にショッピングセンター・市民センター 等の施設が比較的充実していることなどから、「鶴ヶ谷団地」を対象 団地とした。対象団地の位置と特性を図 1 、表 1 に示す。

調査にあたっては、対象団地全世帯に調查できるよう事前に「町 内会長」にお願いし、回覽板で周知のうえ、空き家等を確認しなが ら全住宅に直接訪問しポスティングを行った。回収は返信用封筒で 返信して頂き、回収後未記入の部分があれば後日まとめて戸別に訪 問し情報を補足した。調查の概要は表 $2 、 3$ の通りで平常時と災害後 の交流活動の実態と意識について「直接会話」と「機器通話」での 交流活動について 50 項目 (+自由記述)について調査した。

\section{1 団地別 $\cdot$ 高齢化率、平均年齢}

平成 22 年の国勢調查・小地域集計結果から、仙台市における総人 口が 10,000 人以上の住宅団地の町丁目を抽出し、団地別に高齢化率 と平均年齢を造成時期の古い順に示したのが図 2 である。対象団地 の鶴ヶ谷の平均年齢は、51 歳で高齢化率は $36 \%$ と他の団地に比べ最 も高くなっている。鶴ケ谷団地全体での調查票回収数 1,213 票のう ち戸建住宅は 880 票 $73 \%$ と大半を占め、高齢者数も多いことから本 研究では戸建住宅居住者を分析の対象とした。

\section{2 調査対象者の概要}

調査の結果から、対象者の主な属性として性別・年齢・家族型・ 家族人数・利用機器についてみると以下のようになる（表 4)。

(1)性別：男性 55\%、女性が 45\%。(2)年齢：65 歳未満が 17\%、75 歳以

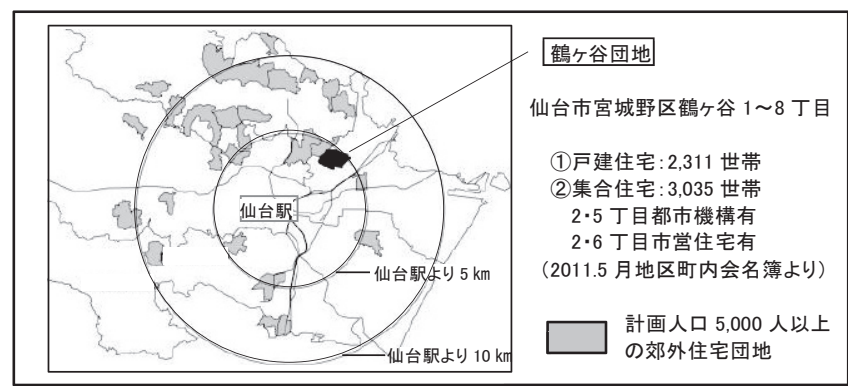

図 1 調査対象団地の位置

\begin{tabular}{|c|c|c|c|c|c|c|}
\hline \multirow{6}{*}{$\begin{array}{l}\text { 鶴 } \\
\text { 先 } \\
\text { 谷 } \\
\text { 地 } \\
\text { 特 } \\
\text { 性 }\end{array}$} & \multirow{3}{*}{$\begin{array}{c}\text { 団地造成概要等 } \\
\text { (鶴ヶ谷 } 1 \sim 8)\end{array}$} & 造成時期 & 面積 & \multicolumn{2}{|c|}{ 計画戸数·人口 } & \multirow{2}{*}{$\frac{\text { 駅·距離 }}{(\mathrm{km})}$} \\
\hline & & (昭和・年) & (ha) & $(\overline{\bar{D}})$ & (人) & \\
\hline & & $43 \sim 50$ & 180 & 5,878 & 23,000 & 4.5 \\
\hline & 住居形態別計画戸数 & \multicolumn{5}{|c|}{ 戸建住宅: 計画戸数2,300一計画人口: 8050、集合住宅: 3,578-14950 } \\
\hline & 主大団地内施設 & \multicolumn{5}{|c|}{ 公園 $12 \cdot$ 小学校 $2 \cdot$ 中学校 1 -高校 $1 \cdot$ 市営住宅·都市機構·保育所 $2 \cdot$ 幼稚園 } \\
\hline & & \multicolumn{5}{|c|}{ 鶴ヶ谷商店街·市場·SEIYU·生協·オープン病院·あおぞらホーム等 } \\
\hline
\end{tabular}

表 2 調査の内容

\begin{tabular}{|c|c|c|c|c|}
\hline & \multicolumn{2}{|c|}{ 直接会話での交流活動の調査項目 } & \multicolumn{2}{|c|}{ 機器通話での交流活動の調査項目 } \\
\hline \multirow{7}{*}{$\begin{array}{l}\text { 交 } \\
\text { 流 } \\
\text { の } \\
\text { 実 } \\
\text { 態 }\end{array}$} & 平常時 & 災害後 & 平常時 & 災害後 \\
\hline & (1)交流回数 & (2)交流回数 & 188交流回数 & (19)交流回数 \\
\hline & (3)交流相手 & (4)交流相手 & 20)交流相手 & (21) 交流相手 \\
\hline & 5)交流場所 & 6)交流場所 & 222利用機器 & (23)利用機器 \\
\hline & (7)交流内容 & 8)交流内容 & 24)交流内容 & (25)交 \\
\hline & \multicolumn{2}{|c|}{ 9)交流回数の変化 } & \multicolumn{2}{|c|}{ (26)交流回数の変化 } \\
\hline & \multicolumn{2}{|c|}{ (10)増えたー(11)減った理由 } & \multicolumn{2}{|c|}{ 277増えた・(28)減った理由 } \\
\hline \multirow{5}{*}{$\begin{array}{l}\text { 交流 } \\
\text { 意 } \\
\text { 識 }\end{array}$} & \multicolumn{2}{|c|}{ (12)交流のつながりの変化 } & \multicolumn{2}{|c|}{ (29)交流のつながりの変化 } \\
\hline & & \multirow{2}{*}{\multicolumn{2}{|c|}{\begin{tabular}{|l|} 
30強くなったー・31弱くなつた $\mathrm{t}$ 理由 \\
322 \\
\end{tabular}}} \\
\hline & \multicolumn{2}{|c|}{ 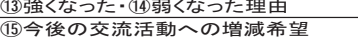 } & & 32) 今後の交流活動への増減希望 \\
\hline & \multicolumn{2}{|c|}{ (16)増やしたい・(17)減らしたい理由 } & \multicolumn{2}{|c|}{ (33)増やしたい.34減らしたい理由 } \\
\hline & & 流活動全般に一 & の意見(フリー & \\
\hline \multirow{3}{*}{ 性 } & \multicolumn{4}{|c|}{ (35)性別-(36)年齡-(37)家族型-(38)居住年数-(39)職業の有無-(40退職前の職業 } \\
\hline & \multicolumn{4}{|c|}{ (41)退職後の職業-(42)血液型-(43)利用交通手段-(44)健康状態-45)住宅形態 } \\
\hline & \multicolumn{4}{|c|}{ (46)外食回数-(47)趣味·(48)交流姿勢-499戸建集合間の交流·(50)自宅の被害箇所 } \\
\hline
\end{tabular}

表 3 調査日 - 調査の戸数 - 配布回収数（住居形態別）

\begin{tabular}{|c|c|c|c|c|c|c|c|}
\hline \multirow{3}{*}{ 鶴ヶ谷団地 } & \multirow{3}{*}{$\begin{array}{l}\text { 団地特性 } \\
\text { 総人口( ) }\end{array}$} & \multicolumn{3}{|c|}{ 総人口·世帯数、単位: 人、世帯) } & \multicolumn{3}{|c|}{ 調查概要(配布·回収数単位:戸、\%) } \\
\hline & & 雀居の & 類別·世戒 & 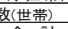 & \multirow{2}{*}{$\frac{\text { 上段: 配布·回收 }}{\text { 一戸戒 }}$} & 数、下段:回収率 & 合計 \\
\hline & & 一戸建 & 長屋·共同 & 合 計 & & 長屋·共同 & 配布数 回収数 \\
\hline \multirow{2}{*}{ 1丁目 } & \multirow{2}{*}{1,253} & \multirow{2}{*}{451} & \multirow{2}{*}{34} & \multirow{2}{*}{485} & \begin{tabular}{l|l|}
438 & 196 \\
\end{tabular} & 40 & 478 \\
\hline & & & & & $45 \%$ & $5 \%$ & $41 \%$ \\
\hline \multirow{2}{*}{ 2丁目 } & \multirow{2}{*}{2,089} & \multirow{2}{*}{1} & \multirow{2}{*}{1,082} & \multirow{2}{*}{1,083} & \begin{tabular}{c|c}
0 \\
\end{tabular} & \multirow{2}{*}{\begin{tabular}{l|l|}
854 & 111 \\
$13 \%$
\end{tabular}} & \multirow{2}{*}{$\frac{854 \mid 111}{13 \%}$} \\
\hline & & & & & - & & \\
\hline \multirow{2}{*}{ 3丁目 } & \multirow{2}{*}{891} & \multirow{2}{*}{314} & \multirow{2}{*}{29} & \multirow{2}{*}{343} & \begin{tabular}{|l|l|}
299 & 129 \\
\end{tabular} & 27 & 326 \\
\hline & & & & & $43 \%$ & $7 \%$ & $40 \%$ \\
\hline \multirow{2}{*}{ 4丁目 } & \multirow{2}{*}{1,260} & \multirow{2}{*}{447} & \multirow{2}{*}{35} & 482 & \begin{tabular}{|l|r|}
429 & 169 \\
\end{tabular} & 33 & \begin{tabular}{|l|l|}
462 & 171 \\
\end{tabular} \\
\hline & & & & & $39 \%$ & $6 \%$ & $37 \%$ \\
\hline 5T目 & & 273 & & & 111 & 323 & 571 \\
\hline 5丁日 & 1518 & $2 / 3$ & 380 & 653 & $45 \%$ & $11 \%$ & $26 \%$ \\
\hline 6丁目 & 2860 & 65 & 1298 & 1363 & 62 & 994 & 1,056 \\
\hline & 2,800 & 05 & 1,298 & 1,303 & $39 \%$ & $16 \%$ & $17 \%$ \\
\hline 7T目 & 1074 & 401 & 23 & 424 & \begin{tabular}{|l|l|}
371 & 170 \\
\end{tabular} & 18 & 389 \\
\hline & $1,0 / 4$ & 401 & 23 & 424 & $46 \%$ & $33 \%$ & $14 \%$ \\
\hline 8丁目 & 774 & 229 & 69 & 298 & 191 & 73 & 264 \\
\hline & & & & & $42 \%$ & $18 \%$ & $36 \%$ \\
\hline 合 計 & 11719 & 2181 & 2950 & 5.131 & \begin{tabular}{|l|r|}
2,038 & 880 \\
\end{tabular} & \begin{tabular}{|l|l|}
2,362 & 333 \\
\end{tabular} & \begin{tabular}{|l|l|}
4,400 & 1,213 \\
\end{tabular} \\
\hline & & & & & $43 \%$ & $14 \%$ & $28 \%$ \\
\hline
\end{tabular}

(注 : $\mathrm{H} 22$ 年度国勢調査データ・10000 人以上の住宅団地)

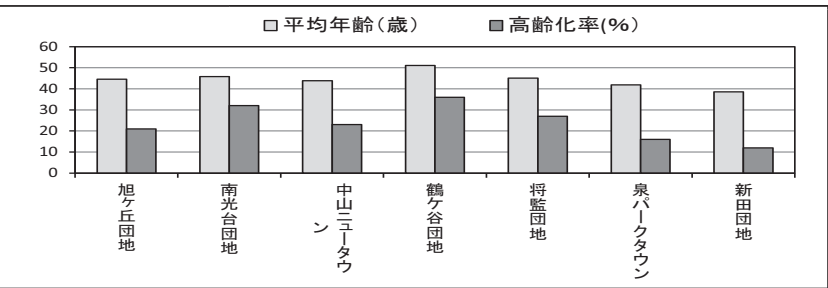

図 2 団地別・平均年齢、高齢化率（H22）

上の後期高齢者が 48\%。(3)家族型：一人暮し 15\%、夫婦のみ世帯が

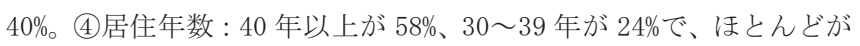
30 年以上である。(5)利用機器 : 家庭用電話が最も多いが携帯電話 (36\%) やパソコン（5\%) を利用している人もみられる。 
表 4 調査全対象者の特性

\begin{tabular}{|c|c|c|c|c|c|}
\hline \multicolumn{6}{|c|}{ 対象者の特性 (性別·年齢-家族型·居住年数- 利用機器) } \\
\hline \multicolumn{2}{|c|}{ 対象者の属性特性 } & \multirow{2}{*}{$\begin{array}{l}\text { 全対象者 } \\
488(55 \%)\end{array}$} & \multicolumn{2}{|c|}{ 対象者の属性特性 } & \multirow{2}{*}{ 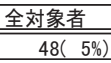 } \\
\hline \multirow{2}{*}{ (1)性 別 } & 男 性 & & \multirow{5}{*}{ (4)居住年数 } & 1 9年 & \\
\hline & 性 & \multirow{2}{*}{$\begin{array}{r}392(45 \%) \\
880(100 \%)\end{array}$} & & $10 \sim 19$ 年 & $63(7 \%)$ \\
\hline Cot mo & 計 & & & \multirow[t]{3}{*}{$20 \sim 29$ 年 } & $55(6 \%)$ \\
\hline \multirow{5}{*}{ (2)年＼cjkstart齢 } & 65歳未満 & $146(17 \%)$ & & & $214(24 \%)$ \\
\hline & $65 \sim 69$ 歳 & $109(12 \%)$ & & & $500(58 \%)$ \\
\hline & 70 74歳 & 199(23\%) & & 計 & $880(100 \%)$ \\
\hline & 75 79歳 & $236(27 \%)$ & \multirow{6}{*}{ (5)利用機器 } & 家庭用電話 & $486(55 \%)$ \\
\hline & 80 歳以上 & $190(21 \%)$ & & 携帯電話 & $307(34 \%)$ \\
\hline \multirow{7}{*}{ (3)家族型 } & & $880(100 \%)$ & & FAX & $4(1 \%)$ \\
\hline & 一人暮らし & $130(15 \%)$ & & パソコン & $41(5 \%)$ \\
\hline & 夫婦のみ & $347(40 \%)$ & & 手紙・はがき & $3(1 \%)$ \\
\hline & 夫婦と子供 & $237(27 \%)$ & & その他(不明) & $39(4 \%)$ \\
\hline & 夫婦と子供·親 & $57(6 \%)$ & & 計 & $880(100 \%)$ \\
\hline & 親と子·兄弟姉妹 & $45(5 \%)$ & \multirow{3}{*}{\multicolumn{3}{|c|}{$\begin{array}{l}\text { 注:家族型で親子とは親のうちどちらかの母または父と子 } \\
\text { の世帯。また、利用機にこついては一番多く利用した機器 } \\
\text { のことである。。 }\end{array}$}} \\
\hline & その他 (不明) & $64(7 \%)$ & & & \\
\hline & 計 & $880(100 \%)$ & & & \\
\hline
\end{tabular}

\section{4. 平常時と災害後の交流活動の変化}

本章では、「平常時」と「災害後」の交流活動の実態の変化を捉え、 交流活動の変化の様相から「問題となるタイプ」を抽出しその特性 を把握することとする。

なお本研究では、地域の社会関係資本の基礎として交流活動を捉 えるという研究の趣旨に照らし、高齢者の割合が多い戸建住宅居住 者を対象とし、近隣・地域住民との交流活動の実態をより直接的に 反映する「直接会話」に焦点を当てて分析することとした。また 4 章では「交流回数の変化」、平常時と災害後の「交流回数」「交流場 所」「交流相手」等の多次元データであらわされる交流活動の変化の 構造の特性を把握するため、まず、数量化而類を適用して多次元デ ータの新たな表現軸を構成し分析を行いその意味づけを行うととも に、居住者属性等の要素との関連性を把握する。また 5 章では、変 化構造の特性をより明確に概念化し、特性別の居住者割合を計量的 に把握するためクラスター分析による類型化を行い、6 章において は変化の基底にある意識の構造をより深いレベルで把握するため自 由記述回答闌の意見内容についての分析を行なっている。

\section{1 数量化正類による「交流活動」の変化の特性}

交流活動の調查項目のうち交流活動の実態を捉える「交流回数」 「交流相手」「交流場所」「交流内容」と平常時と災害後の交流活動 の活発度の変化をあらわす「交流回数の変化」に関するカテゴリー
データ注8) を対象として、数量化類を適用注9) した結果を図 3 に 示す。固有值は第 1 軸で 0.5315 、第 2 軸で 0.4494 で相関係数にす ると $0.73 、 0.67$ である。得られた軸のうち 1 軸は正方向「選択的交

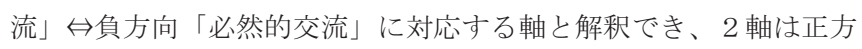
向「団地外交流活動」 $\Leftrightarrow$ 負方向「団地内交流活動」と両軸とも交流 相手を中心として領域を区分する軸と解釈できる。

領域的にみると、 1 軸が負、2 軸が正の領域には、交流相手が「親」 「兄弟・姉妹」「親戚」「子息」、交流場所が「自宅・相手宅」「道路・ 道端」、交流内容が「情報」「テレビ・天気」等に関する会話が位置 しており、身内・家族等の血縁関係の人達との交流に対応する領域 と言える。また 1 軸、2 軸とも負の領域は、「近隣の人」「団地内友 人」と団地内の親しい人と、「週に 3 4 回」程度の「団地内飲食店」 などを使った近隣住民間の交流活動に対応する領域と解釈できる。 次に 1 軸が正の領域では、 2 軸が負の領域が「団地内趣味仲間」と 団地内の集会所やその他の施設を利用した交流活動に対応し、2 軸 の值が 0 近辺の「団地内役員・趣味仲間」との交流に、2 軸が正の 領域が「団地外友人」「団地外趣味仲間」と、団地外仲間との「団地 外飲食店」「団地外施設」等を利用したり「旅行や娛楽」等をする交 流活動に対応する領域と考えられる。

この平面上に「回数」「相手」「場所」「内容」のそれぞれの「平常 時」と「災害後」の平均值をプロットすると、交流回数に関して大 きな差異がみられる。交流回数が「ほぼ毎日」「ほとんどない」と、 交流活動が盛んな人と不活発な人のどちらも災害後 1 軸上の負方向 への変化がみられ、「月 1 回」「年 1 回」等の交流活動が少ない人で は正方向への変化が見られる。災害を契機として、交流活動が活発 (ほぼ毎日) な人は「近隣住民との交流」がより活発となる一方で、 あまり活発でなかった（ほとんどない）人は、交流相手がより家族・ 肉親に特化した傾向があると言えよう。また、その他の交流「相手」 「場所」「内容」についても「回数」の場合と同様に「平常時」と 「災害後」の比較を行ったが、これらについては「回数」ほどの大 きな変化はみられなかった。これから災害の経験は、交流活動の「構 造」そのものに大きな変化をもたらすまでには至っていないと考え られる。

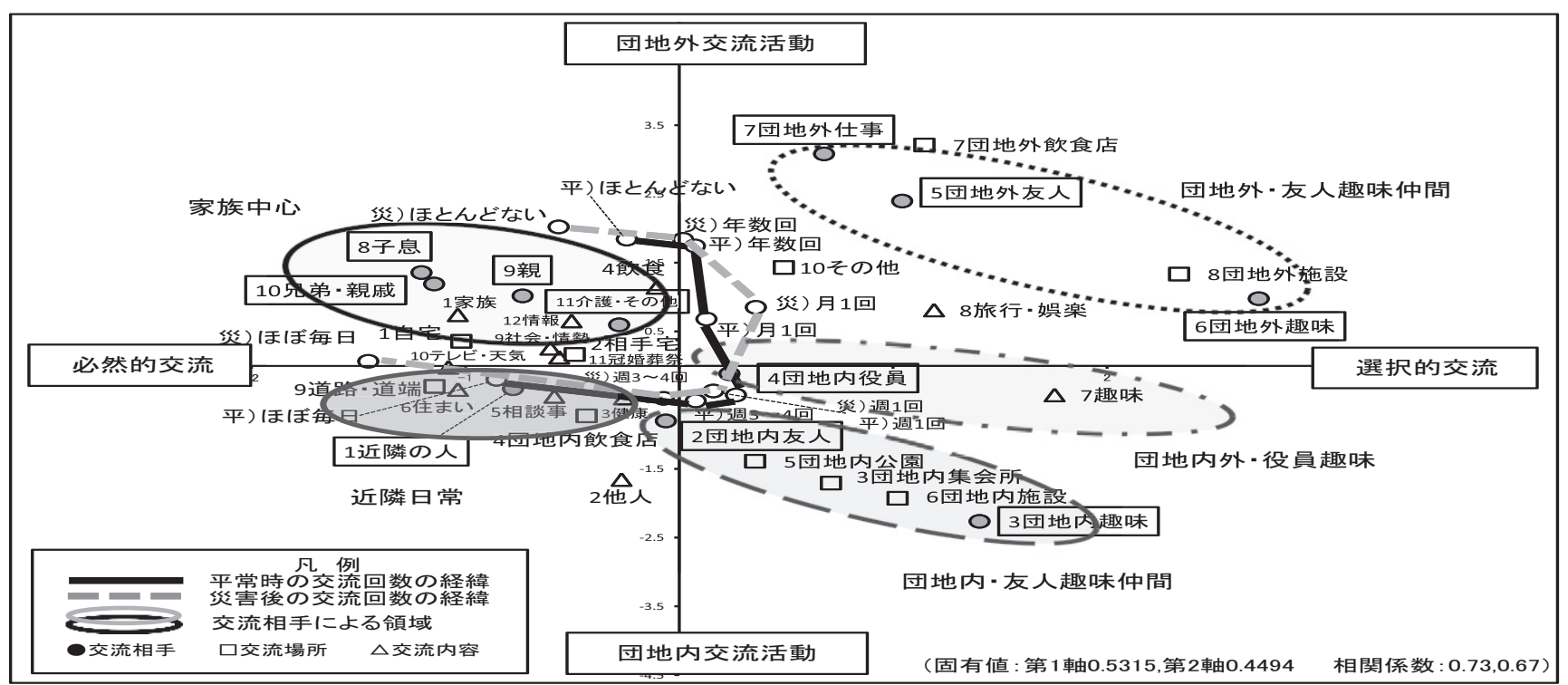

図 3 数量化III類、平常時と災害後の交流活動の実態の変化による領域 


\section{2 居住者属性別の変化の特性}

前節で得られた軸上に、「平常時」と「災害後」の居住者属性（性 年齢、家族型、居住年数、被害箇所）別に求めたそれぞれの平均值 をプロットした結果を図 4 に示す。

性年齢別でみると、男性と女性では大きく領域が異なっている。 男性は 65 歳以上の高齢者はほぼ 1 軸上にあり、災害後負方向に変化 している。変化の幅は「65～69 歳」で最も大きく、次いで「80 歳以 上」となっており、これらの年代では交流活動が災害後、団地内の 友人から近隣の人の側に変化したと言える。これに対し女性では男 性に比べ各年代とも変化の幅が大きく、「75～79 歳」では「団地内 の趣味仲間」 $\rightarrow\lceil$ 団地内の友人」「「65～69 歳」「 $75 \sim 79$ 歳」では「団 地内の友人」 $\rightarrow$ 「近隣の人」の側に変化している。また「65 歳未満」 「80 歳以上」では「兄弟・姉妹」「親」「親戚」等の家族内での変化 がみられるが、多くは交流活動の相手がより近隣となるような方向 へと移行している。また、家族型でみると「一人暮らし」の人は「団 地内友人」 $\rightarrow 「$ 近隣の人」、年婦のみ」の世帯は「団地内役員仲間」 「趣味仲間」 $\rightarrow$ 「友人」「近隣」方向、「夫婦と子供」世帯は「趣味 仲間」 $\rightarrow$ 「親」「兄弟・姉妹」「子息」などと家族の方向へ変化して いるが、全般的にやや近隣の人の方向へと変化している。居住年数 別では、「1〜9 年」「20〜29 年」では家族の領域で負方向への変化が みられ、家族間交流が多くなる一方で、「30〜39 年」「40 年以上」と 居住年数が長い人では「家族」 $\rightarrow$ 「近隣の人」、「団地内友人」 $\rightarrow$ 「近 隣の人」と変化しており、近所付き合いがやや多くなっている。ま た、被害状況でみると、「外壁」「敷地」と被害が大きかった人は、 家族内での変化がみられ、被害状況の相談事や対策などの話し合い 等での交流活動の活発化がうかがえる。それに対し「被害がなかっ た」人は「団地内友人」 $\rightarrow$ 「近隣の人」への変化がみられる。

以上より、全体として居住属性のいずれの面からみても、災害を 契機として地域の交流活動はより近隣との交流が活発化する方向に 変化したと言えよう。

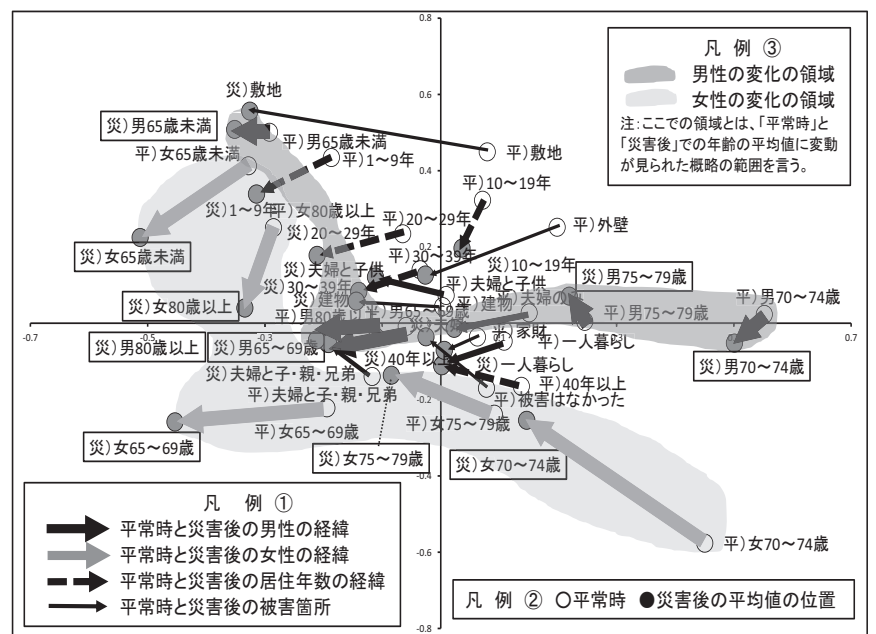

図 4 居住者属性別の変化の特性

\section{3 交流活動の変化の理由}

4.1 で得られた軸上に交流の実態のうち「交流回数の変化」「交流 のつながりの変化」「今後の増減希望」に対する増減・強弱・増減希 望の理由別の平均值をプロットした結果を図 5 に示す。

交流活動への態度の面からみると、1 軸、2 軸とも正の領域は交 流活動に消極的な領域であり、1 軸、2 軸とも負の領域は交流活動に 積極的な領域と解釈できる。注目す心゙きは、交流活動に積極的な領 域では、「増えた」「強くなった」「増やしたい」がまとまっているの に対し、消極的な領域では「減った」「弱くなった」「減らしたい」 がまとまっていることであり、災害を契機にして、平常時に交流活 動に積極的であった層はより積極的になり、消極的であった層はよ り消極的になるという 2 極分解型の変化が進行した様子がうかがえ る。各領域の交流相手から見た場合の特性と重ねてみると、災害を 契機に団地外の選択的交流活動の評価が低下し、近隣の日常的交流 活動の評価が向上している様子が見られ、前述した「交流活動のよ

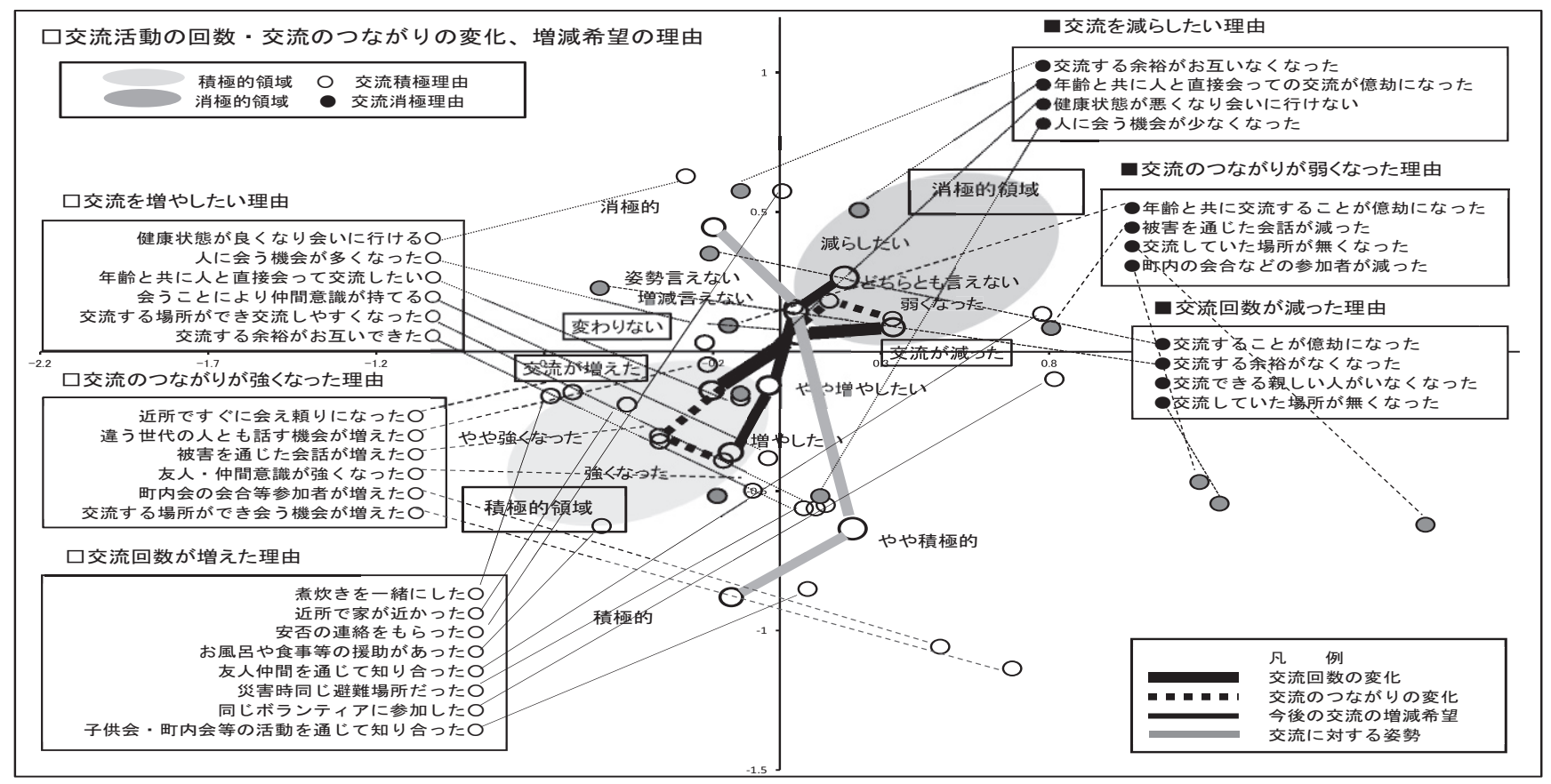

図 5 平常時と災害後の「交流回数」「交流のつながり」の変化の理由・「今後の交流希望」の増減理由 
り近隣化」の傾向は意識の面からも裏づけられると言えよう。

それぞれの変化をみると、交流回数が増えた人は $32 \%$ 、減った人 は $10 \%$ 、っながりが強くなった人は $35 \%$ 、弱くなった人は $6 \%$ 、交 流を増やしたい人は 40\%、減らしたい人は 4\%と交流に対し積極的な 方向に変化した人の方が多くなっている（図 6、表 5)。

\begin{tabular}{|c|c|c|c|c|c|c|}
\hline \multirow{2}{*}{$\begin{array}{l}\text { 増えた } \\
\text { 交流回数の変化 }\end{array}$} & \multirow{2}{*}{$\begin{array}{l}\text { 口やや増えた } \\
\text { 三化 } \\
10\end{array}$} & \multicolumn{2}{|c|}{ ロ変わりない } & \multirow{2}{*}{$\begin{array}{c}\text { ロやや減つた } \\
58 \\
\end{array}$} & \multicolumn{2}{|c|}{ ロ減った } \\
\hline & & 22 & & & & \begin{tabular}{|l|l|}
6 & 4 \\
\end{tabular} \\
\hline & & $20 \%$ & $40 \%$ & $60 \%$ & $80 \%$ & $100 \%$ \\
\hline \multirow{3}{*}{$\begin{array}{l}\text { ⿴囗強くなった ロやや } \\
\text { 交流のつながりの変化 }\end{array}$} & なった & ロどち & 言えな & ロやや弱くな二 & $=$ & くなった \\
\hline & 11 & 24 & & 59 & & 33 \\
\hline & & $20 \%$ & $40 \%$ & $60 \%$ & $80 \%$ & $100 \%$ \\
\hline \multicolumn{2}{|c|}{ 増やしたい 『やや増やしたし } & 口堄 & えない & ロやや減らしたし & ㅁ & ちしたい \\
\hline \multirow[t]{2}{*}{ 今後の増減希望 } & 17 & & & 56 & & 22 \\
\hline & & $20 \%$ & $40 \%$ & $60 \%$ & $80 \%$ & $100 \%$ \\
\hline
\end{tabular}

図 6 交流の回数・つながりの変化・増減希望 $(\%)$

表 5 交流の回数・つながりの変化・増減希望の割合 $(人 \cdot \%)$

\begin{tabular}{|c|c|c|c|c|c|c|}
\hline \multirow{3}{*}{ 交流回数の変化 } & 増えた & やや増えた & 変わりない & やや減った & 減っtた & 合 \\
\hline & $83 \lambda$ & 176人 & 482人 & $52 \lambda$ & 34 人 & 827 人 \\
\hline & $10 \%$ & $22 \%$ & $58 \%$ & $6 \%$ & $4 \%$ & \\
\hline \multirow{3}{*}{ つながりの変化 } & 強くなった & やや強くなった & どちらとも言えない & やや弱くなった & 弱くなった & 合 \\
\hline & 90人 & 199人 & 491人 & 24人 & $23 人$ & 827 人 \\
\hline & $11 \%$ & $24 \%$ & $59 \%$ & $3 \%$ & $3 \%$ & \\
\hline \multirow[b]{2}{*}{ 今後の増減希望 } & 増やしたい & やや增やしたい & 增減言えない & やや減らしたい & 減らしたい & 合 \\
\hline & 142 人 & $\frac{192 \lambda}{23 \%}$ & 462 人 & $\frac{13 \lambda}{2 \%}$ & 18 人 & 827 人 \\
\hline
\end{tabular}

交流回数の変化について、「回数が増えた」理由は「煮炊きを一緒 にした」「近所で家が近かった」「お風呂や食事などの援助があった」 などの近所だからできる付き合いが交流積極領域に位置しており、 「友人や仲間を通じて知り合った」「同じボランティアに参加した」 等活動を通したものが中間的な領域に位置している。一方、「回数が 減った」理由は、「交流することが億劫になった」「余裕がなくなっ た」「交流できる親しい人がいなくなった」「交流していた場所がな くなった」等であり交流相手からみると、家族領域、団地内趣味領 域にあり、これらの領域は「交流積極曰交流消極」の位置関係とは 必ずしも一致しておらず、交流が減った理由と交流の積極性とは必 ずしも強い関係があるとは言えない状況となっている。

これから、交流回数が減った理由と交流の積極性との関連性はそ れほど明確ではないが、増加した理由をみると、近隣における交流 回数の増加は災害時の協力関係の経験が大きく影響していると推察 される。また、交流のつながりが強くなった理由のうち「近所です ぐに会え頼りになった」「友人・仲間意識が強くなった」「違う世代 の人とも話寸機会が増えた」が近隣・交流積極領域に位置し、弱く なった理由のうち「町内の会合などの参加者が減った」「被害を通じ た会話が減った」「交流していた場所がなくなった」が団地内・趣味 領域に位置しており、災害を契機として余裕や施設を必要とする交 流が希薄化する一方で、近隣・日常・必要をキーワードとする交流 が活発化する方向に変化したことがうかがえる。また、今後の交流 を増やしたい理由のうち「健康状態が良くなり会いに行ける」「年齢 と共に人と直接会って交流したい」交流寸る場所ができ交流しやす くなった」交流する余裕がお互いできた」が近隣・交流積極領域に、 減らしたい理由のうち「健康状態が悪くなり会いに行けない」年齢 と共に人と直接会っての交流が億劫になった」「交流する余裕がお互 いなくなった」が中間的な領域に位置しており、今後の交流活動を 増やしたい理由と交流活動の積極性との関連性が明確なのに対し、 減らしたい理由との関連性はやや不明確となっている(図 5)。

\section{5. 平常時 - 災害後の交流活動の実態の変化の類型化}

数量化III類から得られた 1 軸と 2 軸の值を座標軸としてサンプル のクラスター分析（ユークリッド距離、ウォード法）を行い、交流 活動の変化の特性を $5 つ$ つラスターに分類した。クラスター分析 のデンドログラムを図 7 に、各類型のサンプル分布状況を図 8 に示 す。また、クラスター分析の「平常時」と「災害時」の類型からク ロス表を作成し、図 9 に示すように変化の有無から、変化後の交流 範囲が「より内向き」になったか「より外向き」になったかに着目 して、8つの変化類型を設定して特性を見ていくことにする。なお、 変化類型の設定にあたっては、サンプル数を考慮して「団地内外・ 役員趣味型」「団地外・友人趣味仲間型」は「団地外中心」としてひ とつの区分に統合して考えることにした。

\section{1 クラスター分析による類型化}

クラスター分析により 5 つの類型が得られた。類型 1 は交流頻度 が「ほぼ毎日」の人と「ほとんどない」人で親や子息等の家族との 交流が中心の「家族中心型」、類型 2 は交流頻度が高く、ご近所の人 と親しい「近隣日常型」、類型 3 は頻度は週に 3 4 回位の団地内の 友人や趣味仲間との交流が中心の「団地内・友人趣味仲間型」、類型 4 は町内活動の役員や団地外の趣味仲間を通した交流が中心の「団 地内外. 役員趣味型」、類型 5 は団地外の昔ながらの友人や、趣味仲 間との頻度が少ない月・年単位の交流が中心の「団地外・友人趣味

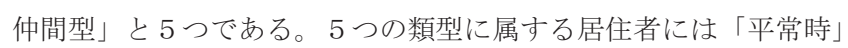
と「災害後」で変化がみられる居住者が存在することから、以下の 分析では平常時における所属類型と災害後の所属類型を新たな居住 者属性と考え、両者のクロス表を作成し、変化の有無から８つの変 化類型を設定して特性をみていく。

ここで設定した 8 つの類型は、災害後に交流相手が家族、近隣の 人、友人、趣味仲間へ変化した層をそれぞれ「变化・家族型」「変化・ 近隣型」「変化・友人型」「変化・趣味型」(「交流相手変化型」) とし、 平常時と災害後とで変化がなかった層をそれぞれ「維持・家族型」 「維持・近隣型」「維持・友人型」「維持・趣味型」(「交流相手維持 型」）としたものである（図 9)。

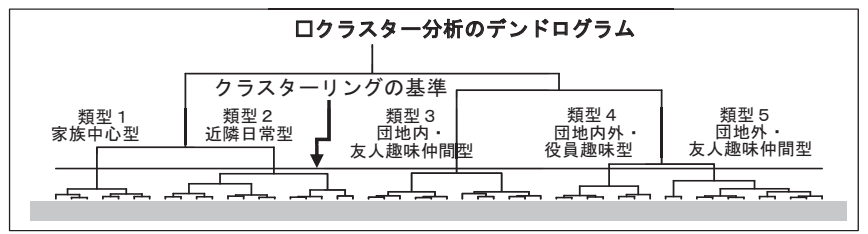

図 7 平常時と災害後の交流活動の実態の変化の類型

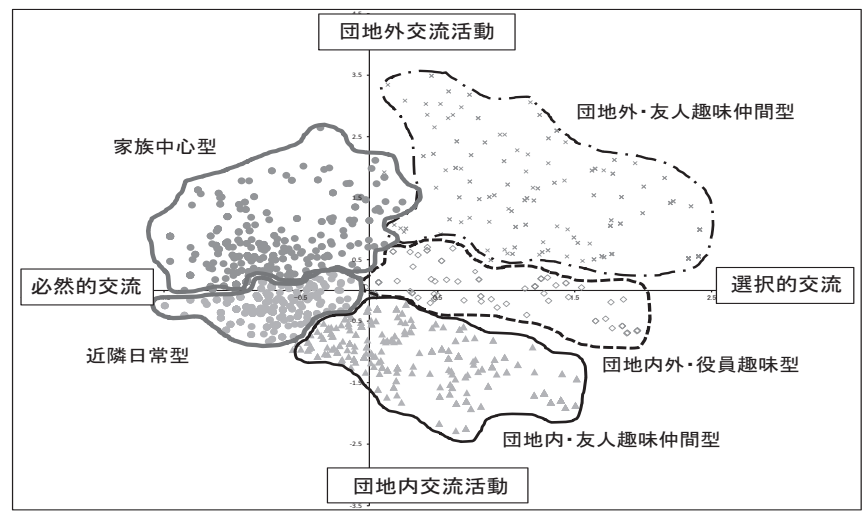

図 8 数量化III類による交流の実態の変化の類型 


\section{2 類型の変化による層の特性}

8 つの類型の割合は「交流相手変化型」 $28 \%$ 、「交流相手維持型」 $72 \%$ である。また交流相手変化型は「変化・家族型 $6 \%$ 「変化・近 隣型 $10 \%$ 」変化・友人型 $6 \%$ 」変化・趣味型 $6 \%$ 、交流相手維持 型は「維持・家族型 19\%」「維持・近隣型 19\%」「維持・友人型 20\%」

「維持・趣味型 $14 \% 」 て ゙ 、$ 平常時と災害後で変化のあった層は全体 の 3 割弱である。また近隣日常型へ変化した人や、近隣日常型を維 持している層が多いことが分かる。

「性」「年齢」「性年齢」「家族型」「居住年数」別に 8 類型の割合を みたのが図 10 である。

性、年齢でみると、全体では「70 歳以上」では「維持・近隣型」 が減少し、「75 歳以上」では「維持・家族型」が増加する傾向が見 られる。また、男性は女性より「維持・趣味型」の割合が多い。変 化した人の割合は女性で多く、変化のうちでは「70 歳未満」で「変 化・近隣型」が目立っている。また、男性も「70 歳未満」と「80 歳以上」で「変化・近隣型」が、「70 歳代」では「変化・趣味型」 が多くなっている。家族型別では、それほど明確ではない注 10) が「一 人暮らし」の人で変化した人の割合がやや多くなっている。変化し た人では家族と近隣方向への変化の割合が比較的多い。居住年数で みると変化した人の割合はあまり差はみられないが、居住年数が「30 年未満」の層では変化のうち、近隣日常型への変化の割合が多く、

「30 年以上」では趣味型への変化が多い傾向が見られる。

以上より平常時と災害後で変化した層は、女性では「70 歳未満」 で近隣日常型への変化、男性では「70 歳未満」「80 歳以上」で近隣 日常型への、「70 歳代」では趣味型への変化が多く、男女とも「60 歳代」を中心とした年代で近隣の人との日常的な交流活動が活発化 する方向へと変化したことが特徴であると言える。また、居住年数 別には、居住年数が「30 年末満」の比較的最近入居した世帯で近隣 日常型一の変化割合がやや多いことから、年齢別の傾向と合わせて 考えると、災害は「60 歳代」の入居時期が相対的に新しい居住者の 近隣交流を積極化する契機となったと推察される。

\section{6 交流活動の実態と意識との関連性}

4、5 章における交流活動の実態の変化からの分析に対し、ここで は調查票の「自由記述回答欄」に着目し、交流活動に対する意識か ら問題となる層を捉え、その特性をみていくこととする。

\section{1 意見内容の分類}

自由記述回答欄に回答したのは、全回答者 827（調查対象者 880 の中から無回答・不明回答数 53 を除く）のうち、363 人で $44 \%$ であ る。回答内容を表 6 の項目に分類注 11$)$ すると、「交流意向 $66 \%$ 」現 在の生活心境・状況 $12 \%$ 」「災害時の生活・被害状況 $5 \%$ 」「現在の

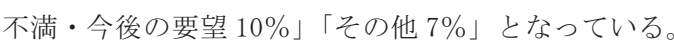

また、交流意向に関して「交流前向」「交流限定」「交流不可」「交 流拒否」と 4 つの型に細分すると、近隣との交流活動に消極的な意 識を持っていると考えられる層は「交流前向」を除いた層で交流意 向意見のうち $58 \%$ と半数以上を占めている（表 6)。

交流活動の変化類型との関係でみると、意見を記述した層のうち、 実態で変化した層の割合は $29 \%$ で全体での割合とほぼ同程度である が意見内容別にみると、「交流不可」「交流拒否」「生活状況」では少 なく、「災害時の状況」「現在の不満」「今後の要望」で多い。「交流

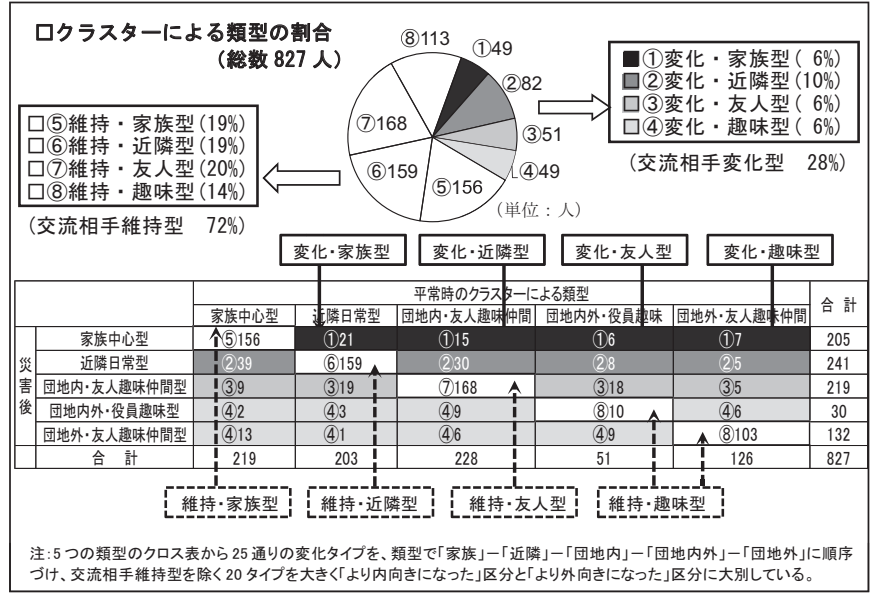

図 9 「平常時」と「災害後」の変化による層

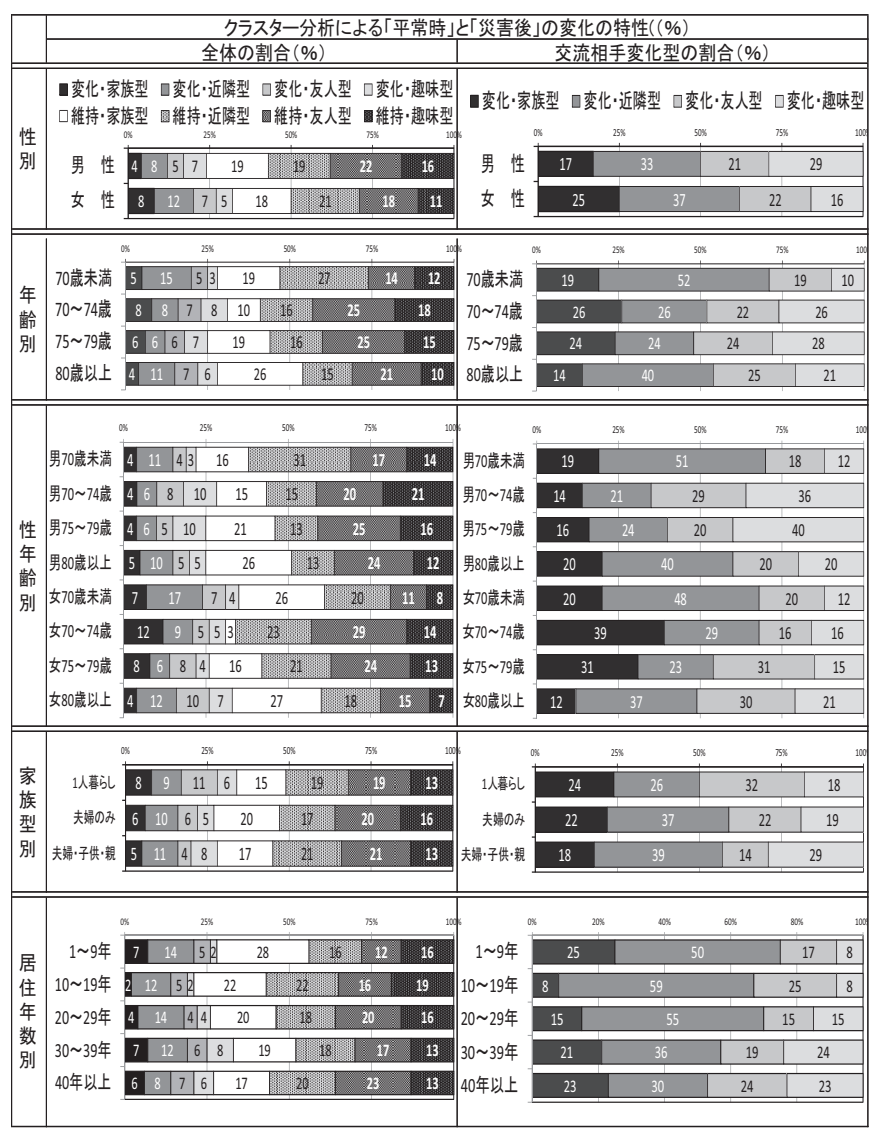

図 10 クラスター分析による層の特性 $(\%)$

不可」「交流拒否」の層はなかなか交流活動の現状を変えにくい状沉 にあると推測される。一方、「交流限定」は「不可」「拒否」に比心゙ ると「変化・近隣型」「維持・趣味型」がやや多くなっており、一般 に「現在の不満」「今後の要望」等の意見を記述した層は前向きの意 見を述べていると考えられ、交流状況に柔軟に対応している傾向が あることがうかがわれる（図 11）。

\section{2 全般的な交流活動をめぐる意見}

交流活動に関する交流意向型は、「交流前向 41\%」「交流限定 19\%」 「交流不可 $32 \%$ 」交流拒否 $8 \%$ 」である（表 7)。

交流前向層をみると、今後の交流に対して以前より多くと考えて いる「前向層」が最も多く、次いで災害を通じて特に近所付き合い 
が改めて大切と思っている「近隣大切層」、今後の交流活動に対して 大きく期待している「期待層」の他、今回の震災での交流活動に対 して、地域の人達に感謝している「感謝層」や、現在、交流活動は 活発だがさらに今後もっと積極的にして行こうと考えている「積極 層」がみられる。交流を限定している層は、相手を「身内・家族」 「近隣・友人」「趣味・スポーツ仲間」「町内会役員」「仕事仲間」「団 地外友人」等としており、中でも団地内外の趣味スポーツ関係の仲 間が多い。交流が何らかの原因で出来なくなっている交流不可層は、 「交流施設」が最も多く、次いで「体調・介護」「住民の態度・マナ 一」「仕事」とする人が多く、その他「町内会組織」「高齢」「世代間 相違」「余裕無」「災害移住」等が要因となっている。

交流拒否層は、「本人の性格」「無関心」などから交流活動に興味 がなく交流不要となっている人と、好きな趣味を楽しむことで満足 している人がみられる。交流活動の変化類型との関係でみると、「交 流限定層」は変化・近隣型が多く、「交流不可」「交流拒否」層は変 化・家族型と変化・趣味型の 2 極化がみられる（図 12）。

\section{3 交流活動に問題となる層の意見内容（事例）}

交流活動の実態の変化の類型で家族や趣味仲間に変化した「変 化・家族型」「変化・趣味型」と、以前から家族や団地外の趣味仲間 と交流し、近隣との交流活動から離れている「維持・家族型」「維持・ 趣味型」を「近隣の交流活動に消極的」な層とし、5 章で得た「家 族中心型」「団地内外・役員趣味型」「団地外・友人趣味仲間型」の 領域にプロットしたのが図 13 である。また、図 13 には交流活動に 関する意識の中で「交流限定」「交流不可」「交流拒否」層を「近隣 との交流活動に消極的な意識を持っている」層とし、実態と意識の 両面で消極的な層の典型的な意見の事例も記載している。

1) 家族中心型の領域

変化・家族型では、「2 3 ケ月前から歩行困難な状況にあり、本 年は不本意ながら町内の行事にはすべてキャンセルしています。」 「老人介護の状況にあり、交流が活発になることを願っていますが、 消極的な立場に立たざるを得ません」と体調や介護の要因から「交 流不可」の意見や本人の性格から交流を拒否寸る意見がみられる。

維持・家族型では、「現在仕事を持っているので帰宅が遅く交流も ほとんどないです」「津波でり災してきたので、近所の方々とはまだ 親しくありません。こちらから入り込めません。私たち今後どうし たら良いか不安です。「すでに出来上がっているグループへの参加 はしにくいです。」等、仕事を持っていることや災害移住、長く居住 していても性格的に入り込めないなどから地域住民との交流が無く 家族との交流が中心になっているケースがあることがうかがえる。

2）団地内外・役員趣味型の領域

交流限定型では、「町内会としての行事に参加していましたがそれ を別に交流活動と言われてもピンとこない。向こう三軒両隣の方々 とも毎日お会いすることもない現状です。」と仕事として町内活動を

行うという義務的な交流活動となっているケースもある。

3）団地外・友人趣味仲間型の領域

交流不可型では、「60 歳まで地域活動に参加していたが、加齢と 共に意欲が薄れ、最近は消極的で自分の体力の事を理由に行動力が なくなった」「公団で 22 年過ごしたが、仕事がなくなり年金が少な く生活が困難なので娘夫婦の所に来た」と、加齢による身体状態が 要因となっている事例や「余裕」「介護」等の要因もある（図 13）。
表 6 意見内容の分類

\begin{tabular}{|c|c|c|c|c|}
\hline \multicolumn{2}{|c|}{ 意見内容の分類 } & 「意見内容による分䫛の概要 & \multicolumn{2}{|c|}{ 意見者の割合(人数:\%) } \\
\hline \multirow{8}{*}{ 交流意向 } & \multirow{2}{*}{ (1)交流前向 } & 交流活動に対して前向、期待、必要、積栖的、感謝，必要てあるととにこつて & \multirow{2}{*}{$100 \curlywedge$} & \multirow{8}{*}{$\begin{array}{c}\text { 合計 } \\
240 \curlywedge \\
(66 \%)\end{array}$} \\
\hline & & 多意見してい㞋層 & & \\
\hline & \multirow{2}{*}{ 2交流眼定 } & 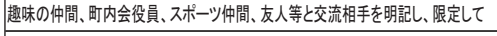 & \multirow{2}{*}{ 45ᄉ } & \\
\hline & & 交流していると意見している層 & & \\
\hline & \multirow{2}{*}{ 3交流不可 } & 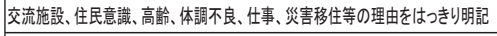 & \multirow{2}{*}{$76 \curlywedge$} & \\
\hline & & し、交流かうまく出来ていないと多人意見している層 & & \\
\hline & \multirow{2}{*}{ (4)交流拒否 } & 交流活動への無閔心、単独的志向、越味志吉向、交流不要等力ら交流を現在必要 & \multirow{2}{*}{$19 \lambda$} & \\
\hline & & としていないと多人意覞している層 & & \\
\hline \multicolumn{2}{|c|}{ 5現在の心境 } & 現在の生活や、今後の生活のあり方等に対する心㑽なとをを多〈意見している層 & 26人 & \multirow[b]{2}{*}{$44 \lambda(1$} \\
\hline \multicolumn{2}{|c|}{ 6現在の生活状況 } & 災害後の現在の生活の状況老多〈意見している層 & 18ᄉ & \\
\hline \multicolumn{2}{|c|}{ 谈害時の生活・被害状況 } & 災害時の生活状況や、被害状況等について多人意見してい層 & 17人 & 17入 $(5 \%)$ \\
\hline \multicolumn{2}{|c|}{ 8現在の不满 } & 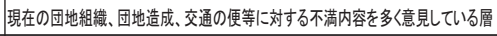 & 18人 & \multirow{2}{*}{$38 \curlywedge(10 \%)$} \\
\hline \multicolumn{2}{|c|}{ 9今後の要望 } & 今後の团地内推設|対しての要望に対し、具体的内容老明碓に意見している層 & $20 人$ & \\
\hline \multicolumn{2}{|l|}{ (10その他 } & アンケートヘの意見等意竟した層 & $24 \lambda$ & $24 \curlywedge(7 \%$ \\
\hline 合 & 計 & 363人(回答者数) $／ 827$ 人(880)；44（\%) & \multicolumn{2}{|c|}{$363 \curlywedge(100 \%)$} \\
\hline
\end{tabular}

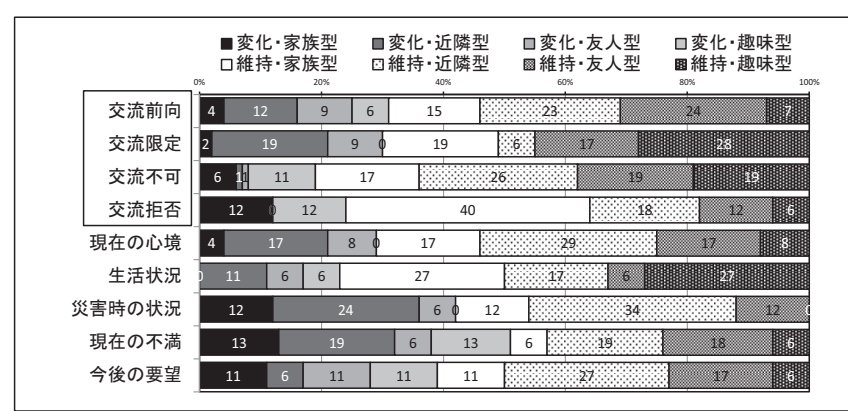

図 11 意見内容の層(意識)と変化による類型(実態), 単位 $\%$

表 7 交流活動に関する意見内容の細分類

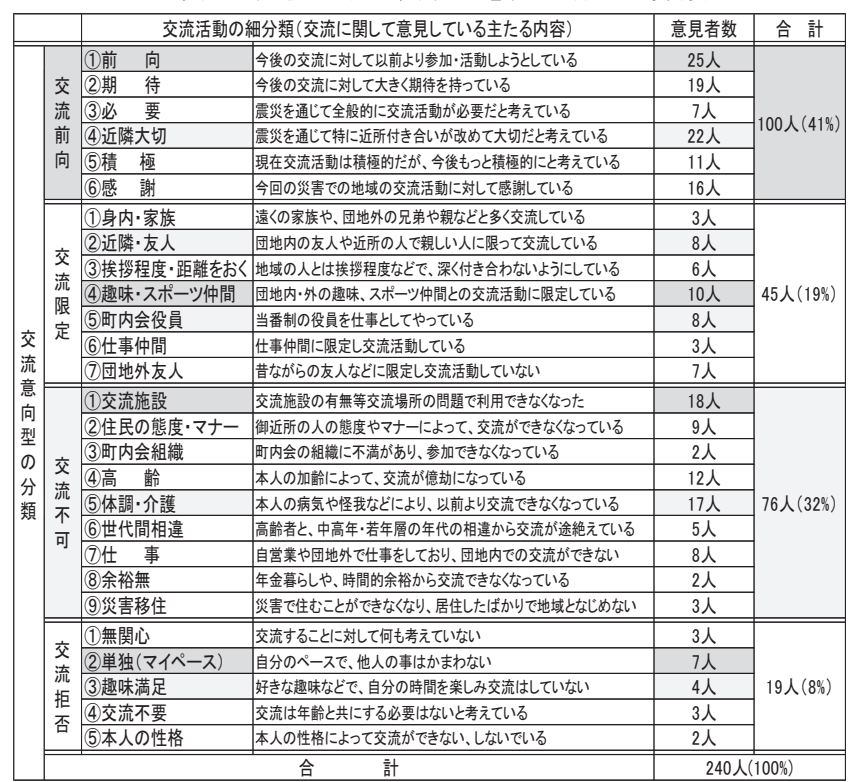

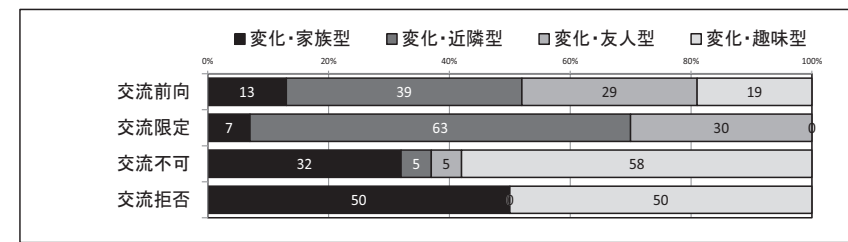

図 12 交流活動に関する型と変化による類型 (\%) 


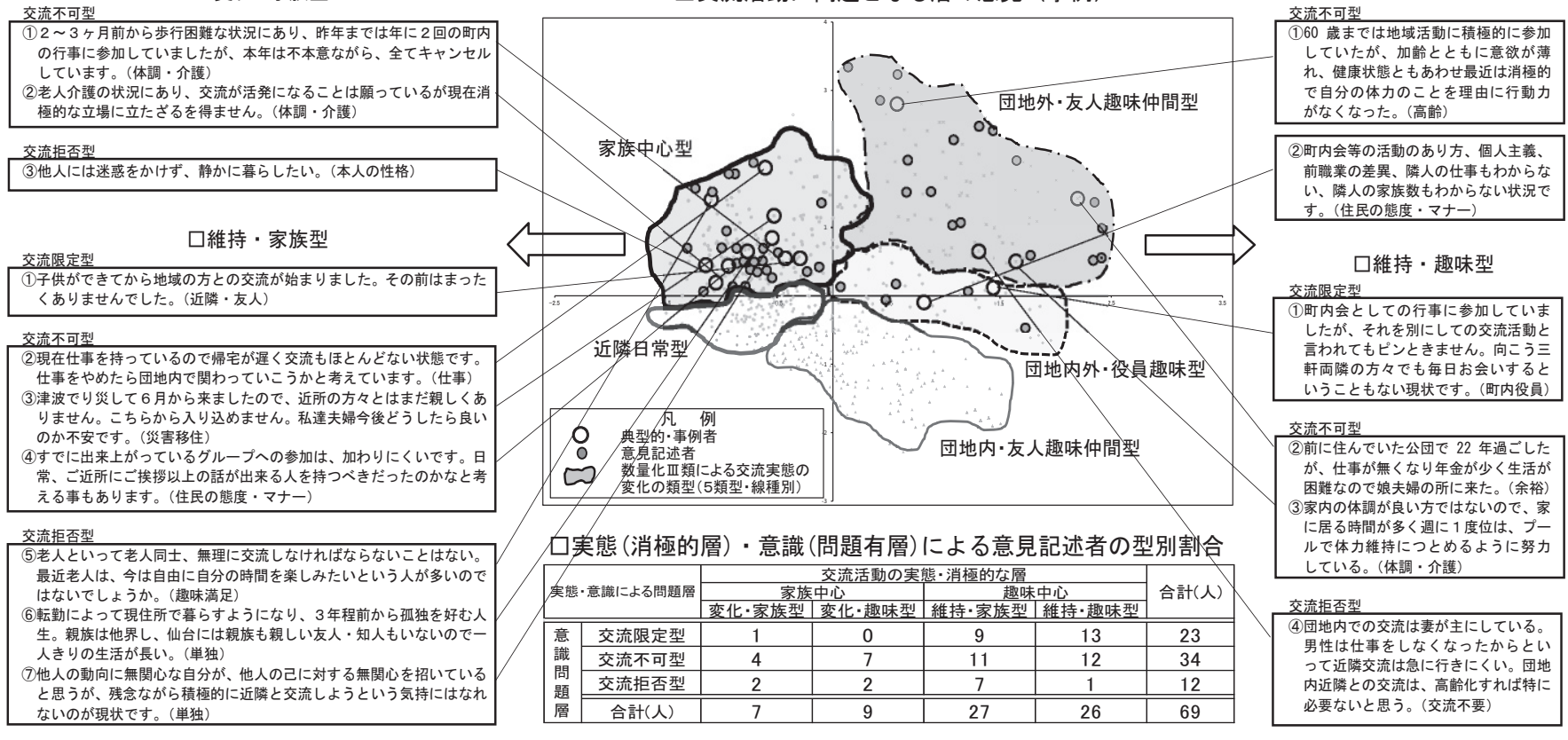

注: 具体例については、自由記述回答欄の記述者のうち、近隣との交流活動に消極的な意識を持っており、実態の面においても近隣交流に消極的である層「69 サンプル」の中から、典型 的な層「16 サンプル」を抽出したものである。(図中央·下の表は、その意見記述者の型別割合「単位 : 人、総数 69 人」を示している。

図 13 交流活動の実態の変化による類型の領域における、「消極的な意識を持っている層」の意見（事例）

\section{4 現在の不満・今後の要望}

問題を持つ層の現在の不満については、「変化・家族型」で「町内 会の活動内容が一部の人の利用」「言葉だけで行動がともなわない交 流」、変化・近隣型」で「町内会組織の問題点」「災害時の町内会の あり方」、維持・家族型」は「避難時の市の対応」「市の側溝工事の 工期」等の問題点が指摘されている。また、要望については全般に 「市民センターの復旧」「集会所の増設」「ショッピングセンターの 改善」「平常時の避難訓練」等が挙げられている（表 8)。

表 8 現在の不満・今後の要望 (事例)

\begin{tabular}{|c|c|c|c|c|}
\hline \multicolumn{3}{|c|}{ 類 型 } & 「現在の不満」「今後の要望」の内容 & 項 目 \\
\hline \multirow{17}{*}{ 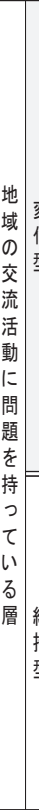 } & \multirow{10}{*}{ 変 } & & $\begin{array}{l}\text { 町内会で費用を応援している囲碁や将棋、卓球等がありますが本当の一部の連中の場になっている。 } \\
\text { 改革す必要あり。普及したりるるど切やっていはい。 }\end{array}$ & 不満 \\
\hline & & & $\begin{array}{l}\text { 震災後「絆」がよく使われます。言葉だげが踊っているような気がする。「コミュニケーション」もその通り } \\
\text { 何かあった場合は声掛けするが、近近所をまわってみるとかな゙具体的に行動とれる呼ひかかけが必要 } \\
\text { である。 }\end{array}$ & 不満 \\
\hline & & 族 & $\begin{array}{l}\text { シゴピングセンターが縮小され衣服や食品も限られた物で不便を感じています。近所に空家が多くな } \\
\text { リました。 }\end{array}$ & 要望 \\
\hline & & & 早〈市民センターがほしい。 & 要望 \\
\hline & & \multirow{6}{*}{ 化 } & $\begin{array}{l}\text { 町内会は地域組織としては、行政の伝達、自治活動、近隣の共助、竌近感の育成等大切な役割を担 } \\
\text { っていると思う。だ高齢化で役員のなり手不足、過度の行政の下請的活動, 若い世代の意識の薄 } \\
\text { 等、共通の問題点は依然多い。 }\end{array}$ & 不満 \\
\hline & & & 災害時の各宅の町内会として安否確認が無かった。当方の親は95歳で外出は出来ず、食料の備蓄 & \\
\hline & & & が少なくなった 10 日目ごろから入手するのに苦労した。自治の最小単位である町内会が平常時から & 不莄 \\
\hline & & & 交流活動方法を工夫して災害時に助け合う仕組みを考えるべきと思う。特に高秢化した町内会には & \\
\hline & & & 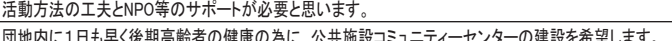 & \\
\hline & & & 集会所が少ないにとと、神社がほしい。 & 要望 \\
\hline & \multirow{7}{*}{ 维 } & 維 & 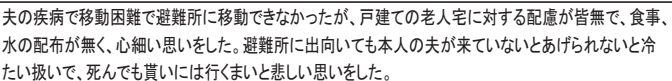 & 不満 \\
\hline & & . & 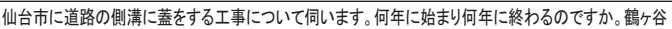 & \\
\hline & & 豕 & 地区の進歩状況は何\%ですか。工事に際しての優先順位はありますか。現在の状態では仙台市の本 & \\
\hline & & & $\begin{array}{l}\text { 格的団地とした造成された鶴ケ谷団地もすでた40年を経過して蓋のないありさまです。画龍点講を欠 } \\
\text { くとはこの状況を指すのではないでようか。 }\end{array}$ & T㭣 \\
\hline & & & $\begin{array}{l}\text { 交流することの目的、必要性、方法が分からない。団地内交流に限定することが必要と考えられる。趣 } \\
\text { 味とか、仕事とか旅行、食べ歩きなどはこ次でいい。㧓独死や自殺の原因となるうつ病などのようなな }\end{array}$ & \\
\hline & & 近 & $\begin{array}{l}\text { 精神的なこと、介護困難者への支援などを見守ってあげられる。地域交流をどうしたら良いか、または、 } \\
\text { どうつくりあげるか。 }\end{array}$ & 不浊 \\
\hline & & 隣 & 平常時訓練をしてほよし。 & 要望 \\
\hline
\end{tabular}

\section{7. まとめ}

本研究から得られた交流活動の実態と意識についての結果をまと めると以下のようになる。

1)平常時と災害後の「交流活動の変化」

交流活動の「回数」「相手」「場所」「内容」に着目し数量化類を 適用した結果、交流の状況の表現軸として「必然的↔選択的」「団地 内 $\Leftrightarrow$ 団地外」の 2 つの軸が得られ、居住者の交流状況は主として交 流相手を中心とした $5 つ の$ 領域で表現できることがわかった。

$5 つ$ 領域は自宅や相手宅での頻度の多い「家族・身内」、道路・ 道端での週 3〜4 回程度の「近隣・向こう三軒両隣の人」、団地内の 集会所や施設で週 1 3 回程度の「団地内の親しい友人」「団地内の 役員・趣味仲間」、団地外での月 1 回 ・年数回位の「団地外の友人 趣味仲間」との交流領域である。得られた軸で構成される平面上に 「平常時」と「災害後」の居住者属性別の平均值をプロットすると、 災害を契機として、平常時に交流活動が活発だった人は、近隣との 交流がより活発化し、あまり活発でなかった人は交流相手が家族・ 肉親に特化する傾向がみられた。また、全体として居住者属性のい ずれの面からみても、交流活動はより近隣との交流が活発になる方 向に変化した。また、変化理由の状況をみると災害を契機とした「交 流活動のより近隣化」傾向は意識面からも裏づけられる。

数量化III類で得られた 1 軸と 2 軸の值を座標軸としてクラスター 分析を行うと「家族中心型」「近隣日常型」「団地内・友人趣味仲間 型」「団地内外・役員趣味型」「団地外・友人趣味仲間型」の 5 つの 類型が得られる。この類型をもとに平常時と災害後の交流状況の変 化についての 8 つの類型を設定し、居住者属性の特徴をみると、災 害は 60 代の入居時期が相対的に新しい居住者の近隣交流を積極化 する契機となったことが推察される。 
2）意識（意見）からみた特性

自由記述回答欄の内容を 10 項目に分類すると、交流活動に関する ものは意見全体の 6 割強で「交流前向 41\%」「交流限定 19\%」「交流 不可 $32 \%$ 」交流拒否 $8 \%$ 」である。「限定」「不可」「拒否」層が「問 題を感じている層」とすると全対象者の約 2 割を占めている。「問題 を感じている層」別に交流活動の変化状況をみると、「交流不可」「交 流拒否」型の人はなかなか交流活動の現状を変えにくい状況にある と推測される。また自由記述回答欄から抽出した理由をみると「限 定」型では相手を「趣味・仲間」を中心とした選択的交流に限定し ている人が多く、「不可」型では「病気」「加齢」「施設」、「拒否」型 では「他人に無関心」「個人的趣味集中」等の理由が挙げられている。

3）現在の不満と要望

事例から「消極的な意識を持っている」層の現在の不満は、「町内 会組織」「災害時の町内会のあり方」「避難時の市の対応」「市の側溝 工事の工期」等町内会組織・行政に対する問題点、要望については 「市民センターの復旧」「集会所の増設」「ショッピングセンターの 改善」等の施設の改善や「平常時の避難訓練」等が挙げられている。

災害後の郊外住宅団地での交流活動はほぼ平常時に戻り、交流実 態の面で変化があった住民は 3 割程度であるが、変化の内容として は各層で「より近隣寄り交流活動の活発化」の傾向がみられ、災害 時の地域の活動を通して「必要」「感謝」「大切」等と意識の中では 新たな認識が生まれ「心の変化」にはかなりのものがあったと推察 される。一方で災害を契機として、近隣交流が活発であった人はさ らに活発に、あまり活発でなかった人はさらに不活発になるという 格差拡大型の傾向もみられた。前述したように「交流限定」層や「交 流拒否」層は意識の面でなかなか変化しにくい傾向を持っているが、 社会関係資本の観点からは、少なくとも災害時にはこれらの層につ いても地域活動に積極的に参加してもらうような方策の検討が望ま れる。ただ、意識面での変革はなかなか難しいと推測されるので、 これらの層の交流に対する価值観を尊重しつつ、あまり抵抗感無く 参加できるような近隣交流の場の設定や参加を促す䨌囲気の醸成方 策についての検討が必要であると思われる。

また、本研究では分析の対象を団地内の戸建住宅居住者の「直接 会話」での交流活動に限定したが、今後は集合住宅居住者について も分析対象とするとともに、機器を用いた交流の補完的役割等につ いても検討していくことが課題であると考えられる。

注 1)「高齢者の直接会話と機器を利用した交流の実態及びその意識」に関す る調查で、平成 18 年 $10 \sim 11$ 月に仙台市郊外にある「桜ヶ丘団地」「中山 $\mathrm{NT}$ 「将監団地」で行った。総数は 206 戸で回収率は $95.8 \%$ であった。 注 2）「語」の分析とは、テキストマイニングを用いた自由記述回答欄の文章 を名詞・動詞・形容詞・複合名詞としてデータ化して分析したものである。

注 3) 通信機器とは、ここでは家庭用電話、携帯電話、F A X, パソコン、手 紙・はがきとしている。

注 4) 社会関係資本の定義については、Jコールマン、Rパットナム、西出優 子、稲葉陽二、内閣府等で簡潔に整理されているが、それらは「個人間の つながりを基礎とした互酬性・信頼性を持った社会的ネットワークの存在」 がその基本概念であり、この観点から交流活動は地域の基本的な「個人間 のつながり」を示すものであることから、社会関係資本が存在するための 前提条件として位置づけられる。この観点からすると、現在、高齢化の進 行にともない団地内での地域間交流活動が稀薄化しつつある郊外住宅団
地は、社会関係資本の面で「問題」を抱えている地域であると考えられる。 注 5）「災害前」ではなく「平常時」としたのは、これまでの通常（日常）の 地域の人達との交流活動を指すことをより明確にするよう意図したため である。

注 6) 調査票の最後の項目で、「口最後にその他、交流活動全般についてなに かご意見がありましたら教えて下さい。」としたもので、直筆で記入して いただいた「フリーアンサー」である。

注 7）仙台市において、計画人口が 5,000 人以上は 28 団地、 10,000 人以上は 7 団地ある。

注 8）数量化恧類における分析データのカテゴリーは 45 項目で、下記の通り の内容である。

\begin{tabular}{|c|c|c|c|c|c|c|c|}
\hline 害態 & \multicolumn{7}{|c|}{ 交流の実態の力デゴリー項目（図3·図中） } \\
\hline 交流回数 & 1.交流回数 & 2.ほぼ毎日 & 3.週3 4回 & 4.週1回位 & 5.月1回位 & 6.年数回位 & 7.ほとんどない \\
\hline 回数の変化 & 1.回数が增えた & 2.やや増えた & 3.どちらとも言えない & 4.やや蔵った & 5.回数が増えた & & \\
\hline \multirow{2}{*}{ 交流相手 } & 1. 近隣の人 & 2.団地内友人 & 3.団地内趣味 & 4. 団地内役員 & 5.団地外友人 & 6.団地外趣味 & 7.団地外仕事 \\
\hline & 8 .息 & 9.親 & 10.兄弟·親族 & 11.介護·その他 & & & \\
\hline \multirow{2}{*}{ 交流場所 } & 1.自宅 & 2.相手宅 & 3.団地内集会所 & 4.団地内飲食店 & 5.団地内公園 & 6.団地内施設 & 7.団地外飲食店 \\
\hline & 8.団地外施設 & 9:道路·道端 & 10.その他 & & & & \\
\hline \multirow{2}{*}{ 交流内容 } & 1 . 家族 & 2.他人 & 3.健康 & 4.飲食 & 5.相談事 & 6.住まい & 7,趣味 \\
\hline & 8 8旅行·娯楽 & 9.社会・情劸 & 10.テレビ·天気 & 11.冠婚䔦祭 & 12.情報 & & \\
\hline
\end{tabular}

注 9）数量化III類の適用にあたっては回収サンプル 880 の内、記入もれのあ るもの等を除いた 827 サンプルを使用して分析を行った。

注 10）独立性の検定結果の有意水準は $13 \%$ 程度である。

注 11）分類に当たっては、表 6 に示す通りであるが意見内容については、文 面の中で一番多く記述されている内容を優先させ総合的に判別している。

\section{参考文献}

1）吉村東他 : 郊外住宅団地における社会関係資本としての高齢者の交流活動 の意向、住宅系研究報告会第 5 回, pp35-40、2010

2) 吉村東他 : 郊外住宅団地戸建住宅に居住する高齢者の交流活動に関する意 識、住宅系研究報告会第 6 回, pp75-82、2011

3）高畠陽平他 : 阪神淡路大震災復興市街地における再建戸建住宅による住宅 地としての景観特性に関する研究，都市計画論文集，N035，pp397-402， 2000. 10

4）小浦久子他：市街地更新による景観変容に対する居住者の評価と地域景観 イメージ-震災後の建物更新市街地における戸建住宅の表構えの評価から , 都市計画論文集，N038-3，pp661-666，2003.10

5）浅井保他：街区特性から見た住宅再建過程一阪神淡路大震災後の神戸市東 灘区住吉地区を対象として一，日本建築学会計画系論文集，N0545， pp207-214，2001.7

6）落合知帆他 : 大規模災害からのコミュニティの再構築とコミュニティの問 題対応能力に関する研究：インドネシア, アチェ州ムラボーの仮設住宅 を事例として，都市計画論文集，44(3)，pp325-330，2009. 10

7）大江七恵他: 公営住宅におけるコレクティブハウジングのコミュニティ形 成に関する研究一ひょうご災害復興型住宅の入居後一年半の変化より, 都市計画論文集, 35, pp25-30，2000, 10

8）三浦研他: 雲仙岳災害に伴い建設された災害復興住宅におけるコミュニテ イの変化実態一地域防災力形成から見た構築環境の役割を視点として, 都市計画論文集, 31，pp811-816，1996, 11

9）越山健治他：災害時における大規模住宅供給に関する考察—1985 年メキ シコ地震における住宅再建計画について，都市計画論文集，35, pp415-420, 2000. 10

10）J. コールマン：社会理論の基礎、久慈利武訳、青木書店, 2004

11）R. パットナム：孤独なボーリング、柴内康文訳、柏書房, 2006

12）R. パットナム：哲学する民主主義、河田潤一訳、NTT 出版, 2001

13）西出優子: 中山間地域とソーシャル・キャピタル、地域開発, Vol150, pp2-6 , 2010, 7 